\title{
WILEY

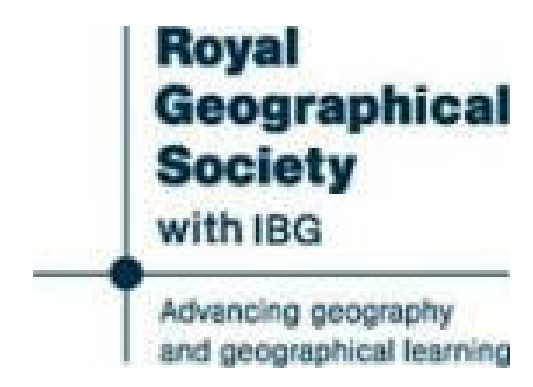

Journey to Shigatze, in Tibet, and Return by Dingri-Maidan into Nepaul, in 1871, by the Native Explorer No. 9

Author(s): T. G. Montgomerie

Source: Journal of the Royal Geographical Society of London, Vol. 45 (1875), pp. 330-349

Published by: Wiley on behalf of The Royal Geographical Society (with the Institute of British

Geographers)

Stable URL: http://www.jstor.org/stable/1798714

Accessed: $28 / 06 / 2014$ 13:10

Your use of the JSTOR archive indicates your acceptance of the Terms \& Conditions of Use, available at

http://www.jstor.org/page/info/about/policies/terms.jsp

JSTOR is a not-for-profit service that helps scholars, researchers, and students discover, use, and build upon a wide range of content in a trusted digital archive. We use information technology and tools to increase productivity and facilitate new forms of scholarship. For more information about JSTOR, please contact support@jstor.org.

Wiley and The Royal Geographical Society (with the Institute of British Geographers) are collaborating with JSTOR to digitize, preserve and extend access to Journal of the Royal Geographical Society of London. 
tested under an air-pump at Kew, when it was found to agree at every inch of pressure from the normal height down to 11 inches.

A similar difference was given by another aneroid that was sent up to the Thok-Jalung gold-fields; this was supposed to have arisen from some accidental fault.

Captain Basevi, when employed in the elevated ground in the south and north-east of Ladák, was supplied with a similar aneroid, and noted in his memoranda that the observations taken with it were quite unreliable at great altitudes, as he found that even by gentle tapping on the case the index varied its reading, and was always movable in that way no matter how long he remained at a point.

The only conclusion that can be come to, from the three trials referred to, is that in their present shape aneroid barometers cannot be relied on alone at great elevations until they have actually been tested; and they should always be supplemented with either occasional observations of an ordinary mercurial barometer or of a boiling thermometer, at any rate until some satisfactory proof of their reliability has been given, the errors apparently not showing when the aneroid was at rest, and kept at much the same temperature.

It will be noticed that the explorer actually went along a small portion of the great Brahmaputra river below Shigatze, thus adding to our knowledge of its actual course; no iron suspension bridge was however seen there, such as Turner supposed to exist near Shigatze. The explorer was much struck with the magnificent glaciers to the south of the Namcho, or Tengri Núr Lake, and they will no doubt prove to be very extensive, as the man is a good judge of their size, being well acquainted with Himalayan glaciers near India.

Altogether the explorer has done very good service, and in this first altogether independent expedition has shown a large amount of skill, observation, and determination. I trust hereafter he will still farther distinguish himself.

XII.-Journey to Shigatze, in Tibet, and Return by DingriMaidan into Nepaul, in 1871, by the Native Explorer No. 9. By Lieut.-Colonel T. G. Montgomerie, R.E., F.R.s., \&c., Deputy-Superintendent G. T. Survey of India.*

The native explorer whom I designate as No. 9, for one portion of his work, made his way from Iárjiling, passing through Sik- 
kim into Great Tibet; it is not, however, necessary to refer to his journey in detail until he got beyond what Dr. Hooker called the Wallangchoon Pass, as up to that point Dr. Hooker has already given us an admirable description of the country.

The explorer, on trying to pass into Tibet, was, as usual, stopped, and told that he would not be allowed to proceed farther, as he was not known to any one, nor able to give any satisfactory evidence as to his being what he stated. He was consequently rather in despair, but was fortunate enough to ingratiate himself with the chief official of a large Sikkim district whose wife happened to be very ill. I have always made my explorers take a supply of medicines with them, mostly of native kinds, with only a few ordinary European sorts to present to people on their journeys. In the present instance, the explorer had also provided himself with a Hindi translation of a treatise as to using these drugs, and, when he heard of the woman's illness, he offered to give her some medicine if he was allowed to see her and hear as to her sufferings, \&c.; his offer was at once accepted, and the explorer having seen her, searched his book until he came across some disease with the same symptoms as she had, and he then boldly prepared the medicines directed and gave them to the woman according to the instructions, and awaited the result in not a little trepidation. In a few days' time the woman became wonderfully better, and eventually a cure was effected, very much to the astonishment of the amateur practitioner. The explorer was treated with marked kindness and hospitality from the day the woman began to improve: he then again urged his request to be allowed to pass into Tibet. The headman said he would be glad to give him permission, but that it would be of no use, as he would be again stopped by another official before he advanced very far, unless he had some one to answer for him. The explorer, however, continued to urge his point, and at last the official said he would himself be his security, and he finally sent one of his own men with the explorer, who passed him through the places where he was likely to be stopped.

The explorer consequently marched on without any further interruption, except the ordinary ones at custom-houses, where his baggage was strictly searched; fortunately his instruments were so well concealed that they were never discovered.

From the Tipta-La-tbe Wallangchoon Pass of Dr. Hooker, probably so named from the village south of it, which the explorer gives as Wallungsum - he made his way in two marches to Tashirak. The road was a difficult one, the ground north of the pass being very elevated and barren, so that both food and fuel had to be carried on yáks for the use of the party. 


\section{Montgomerie on Trans-Himalayan Explorations, 1871.}

The Tipta-La was covered with snow ; it is on the watershed of a very high range that runs nearly east and west, forming the boundary between Nepal and Lhása.

Tashirak is a large standing Bhotia encampment on a feeder of the Arun River, which rises in a glacier to the west, and not on the main stream of that river, as was formerly supposed; it is 15,000 feet above the sea. Marching north, the explorer crossed the Nila-La Pass, and, passing a large Láma monastery, reached the Shara village of some 50 houses, which is under a Thánahdár of the Tinki or Tinka district, generally known as Tinkijong after its fort (jong). Here his baggage was very closely searched, and it was only by means of the man sent by the Sikkim official that he was able to advance farther. After many inquiries were made, he got a pass to travel to Shigatze, and, being fairly in Tibet, he was never stopped again. He made his way first to Lámádong, a village of 50 or 60 houses, arriving there on the 4th September. Before reaching this place the explorer had latterly seen no cultivation except that of Indian-corn in small quantities, but at Lámádong itself there was a good deal of wheat and peas, and round about several other villages could be seen equally well cultivated; all these villages were on or near the banks of the great eastern branch of the Arun River, called the Khantongiri River, which comes from the east.

The next day he arrived at another small village with plenty of cultivation, all tending to show that he had again reached a warmer climate, Lámádong being 13,100 feet above the sea.

On the 6th September he crossed the Tinki-La Pass, and after a trying march reached the village of Tashichirang on the bank of the Chomto Dong Lake, which is a fine sheet of water about 20 miles in length by 16 miles in breadth, at an elevation of 14,700 feet above the sea. This lake has never been shown in any map that I am aware of, but we have notice of its existence in itineraries collected by Mr. Hodgson, Dr. Campbell, \&c. The explorer found the water very clear and pure, and very good to drink: he and his party used it, and were told that the inhabitants took it in preference to that of the two or three streams which were seen to run into the lake. The explorer was unable to go completely round it, but he could see it fully as he passed along its northern shore, and yet could discover no signs of an outlet; the inhabitants declare that it has none: the sweetness of the water, however, is against there being no outlet, and if so it must be somewhere to the southeast. The lake forms a portion of the boundary between Sikkim and the Lhása territories, the Sikkim territory lying to the east, and that of Lhása to the west of the lake. Several 
very high snow-peaks were visible from the lake to the east and south.

On the 7th September he arrived at Nangji, a Sikkim village, which, though it has but 50 houses, boasts of a wonderful number of dogs, the explorer declaring he himself saw at least 200, and was certain that he never met with such a large proportion in a Tibetan village, where they are proverbially numerous.

On the 9th September he reached Chajong (Tatápáni) hot springs, where he took latitude and thermometer observations, the latter making it 15,000 feet above the sea. Four reservoirs, each about 30 feet in circumference and 3 feet deep, have been built to catch the water of these springs, which appeared to be sulphurous, and have a high reputation for their curative properties, being visited by numbers of people. The place swarmed with Tibetan (Hodgsonian) antelope, which are quite tame, being never disturbed, as they are considered to be dedicated to the deity of the hot springs. The next day the party encamped in a ravine, and the day after crossed the Lagulung-La Pass, which has quantities of glacier-ice close down to it, being itself 16,200 feet above the sea. This pass forms the boundary between Sikkim and Lbása; the march terminated at the village of Thak. On the 15th September he passed the village and post of Sai-Jong, which is surrounded by cultivation, and has numerous other villages round about; encamped at Chota-Tápu or Darcha village on the banks of the Sai-Jong stream, which comes from a great distance, rising in Sikkim. The next day he crossed the Gyaling Mountains by a pass covered with snov, and reached the Bálu Koti village of 20 houses; this place has a good deal of cultivation, and numerous other villages are visible round about it. Passing thence through a level and well-cultivated country, the explorer reached shigatze on tlee $17 \mathrm{th}$ of September.

The explorer paid the usual homage to the Láma of Tashi Lumbo, making an offering of two rupees. He found the city of Shigatze in much the same state as described by the cbief Pundit; he, however, heard of the serious rebellion which had been raised against the great Láma of Lhása in April, 1871, during which hundreds of people were killed.

The explorer remained in Shigatze till the 29th of September; he then made his way south-westwards, towards the Dingri Maidán, resuming his route survey on the 30th September from a point he had previously visited. By evening he reached the village of Shimrang, and the next day crossed the Shabki-Chu River, which was 65 paces wide and 4 feet deep, flowing down into the Sang-po (Bráhmáputra); numbers of villages were seen on and off the road. The harvest was being reaped. 
On the 2nd October he reached the great Shakia monastery (Gonpa), which is only second to that of Tashi Lumbo. The explorer was unfortunately not able to stop at Shakia to examine the place more closely. He says the Shakia monastery is on a low spur ; it is inhabited by about 2500 monk Lámás, ruled by a great Láma, called Shakia-Gangma (king, or above all others); he is looked upon as a deity. His Lámás are the only ones in this part of Tibet that are allowed to marry; they are called Dhukpás, other Lámás who are not allowed to marry being called Gálupás. The town of Shakia lies at the foot of the monastery and is about half the size of the city of Shigatze. About fifty of the shops in the town are kept by Niwars from Nepal; all the other shops are kept by Bhotias. There is a large amount of cultivation around Shakia, though it is about 13,900 feet above the sea.

On the 3rd of October the explorer crossed the Dongo-La, and again got into ground drained by the Arun River, and on the 5th October reached the Chokuar village, on the left bank of the Phungtu or Dingri-Chu River, the great western branch of the Arun River.

Continuing westwards along the Dingri-Chu River, the explorer reached the Sakar-Chu River, a branch of the DingriChu. The Sakar-jong (fort) is about 8 miles north of the junction, and is the residence of a Lhása magistrate. The Ghurkas in 1854 advanced as far as this point when they invaded Tibet.

On the 8th of October the explorer reached the town of Dingri, which is generally known as Dingri Maidán, from the large open plain in which it stands ; it is also sometimes called Dingri-Ganga. The town has but 250 houses, supplemented with tents on occasions of fairs, \&c. ; it is 13,900 feet above the sea.

Five miles above the junction of the Shakar-Chu River, the explorer crossed the Dingri-Chu River by a wooden bridge, seventy-five paces in length-showing that even at that point this great eastern branch of the Arun is a very large stream, as might be expected from its draining the great Dingri tableland.

North, and quite close to the Dingri town, stands the Dingri Khar (fort), on a low isolated hill. A high Chinese officer, called a Daipon, who is the chief military and civil officer, resides in the fort; he has a small garrison of Bhotia soldiers, with but one gun.

From Dingri there is a very good road which runs north-west to Jong-ka-Jong, and thence by Kirong town to Katmándu. Officials are, however, the only persons who are allowed to 
travel by this route, traders and all others taking the one followed by the explorer to Nilam, \&c.

The explorer did not make any stay in Dingri, being afraid that he might be cut off from India by an early fall of snow : he accordingly pushed on as fast as he could. At first he passed through a wide all but level tract, and then getting into. rougher ground reached the Thung-lung-La on the 10th of October; he found the pass covered with old ice and snow, it being 18,460 feet above the sea.

On the 11th of October he reached the town of Nilam, 13,900, feet above the sea, which has about 250 houses. It is ruled by a couple of Jongpons, the Lhása Government sending two there so as to be a check on one another. Nilam being the first Tibetan town on the road from Nepal, is considered to demand extra vigilance, and consequently the explorer and his party were very closely examined and their baggage was carefully searched before they were allowed to go on.

From Shigatze to the Thung-lung-La pass, the explorer had passed through a moderately level tract, though at a very great elevation, but from the Thung-lung-La, where he crossed the Himalayan watershed, he again entered on very rugged ground, much more difficult than even that south of the Tipta-La (or Wallungsum Pass).

Between Nilam and Listi Bhansár he followed the general course of the Bhotia-Kosi River, and though it is but some twenty-five miles direct distance between the two places, the explorer had to cross the Bhotia-Kosi River fifteen times, by means of three iron suspension, and eleven wooden bridges, each of from twenty-four to sixty paces in length. At one place the river ran in a gigantic chasm, the sides of which were so close to one another, that a bridge of twenty-four paces was sufficient to span it. This was just below or south of the village of Choksum. Near this bridge the precipices were so impracticable, that the path had of necessity to be supported on iron pegs let into the face of the rock-the path being formed by bars of iron and slabs of stone stretching from peg to peg, and covered with earth. This extraordinary path is in no place more than eighteen inches, and often not more than nine inches in width, and is carried for more than one-third of a mile (775 paces) along the face of the cliff, at some 1,500 feet above the river, which could be seen roaring below in its narrow bed. The explorer, who has seen much difficult ground in the Himalayas, says he never in his life met with any thing to equal this bit of path. It is, of course, quite impassable for ponies or yáks, and but very few sheep and goats even go by it, though it is constantly passed by men with loads. 


\section{Montgomerie on Trans-Himalayan Explorations, 1871.}

There are several other smaller pieces of paths between Nilam and Listi Bhansár which are nearly as bad, but they are fortunately not continuous.

From Listi Bhansár the explorer's route does not call for any special notice, here being much the same as that in any other part of the mountains south of the Himalayan watershed, being rugged in the extreme for a considerable distance, and then becoming easy in the valleys or Dúns. It may, however, be noted that the explorer crossed the Indrawati feeder of the Kosi, which has five small tarns near its source, called Panch Pokri. The source is in the snowy mountains to the west, as shown on the map.

The lower ground, though not at all noteworthy in itself, had never been surveyed in any way previously, the only land marks being the few great peaks in its neighbourhood, that have been fixed from a distance by the Great Trigonometrical Survey, and I consequently consider the survey of it and other portions of the lower ground a very valuable addition to the geography of that part of the mountains.

On reference to the map, it will be seen that by this exploration the position of the great Himalayan watershed has been determined in three different places. In each case it proves to be far behind or north of the lofty peaks that are visible from Hindustán, such as Mount Everest, Kanchinjinga, \&c.

The explorer, it will be seen, went completely round Mount Everest, but his route was so hemmed in by great mountains that he never got a view of Mount Ererest itself; it seems to have been invariably hidden by the subordinate peaks which are tolerably close to it. Possibly it may have been seen, but never continuously so as to be able to recognise it again, and to fix it by bearings with a moderately long base. The Kanchinjinga and Junnu peaks were, however, seen from the west of Taplang Jong, but only a short base could be secured. The explorer was much impressed by Kanchinjinga; it is known to the natives near Taplang as Kumbh Karan Langirr. The people south of the Himalayas, in Nepal, call all snowy mountains Langúr, by which they mean the highest points. They call the peaks that have no snow Banjung, and the low ground under the said Banjung they call Phedi. The term Himalayas is not used by uneducated people, who only talk of the snowy mountains as "Barfáni Langúr."

Neither the Bhotias nor the Ghurkas seem to have specific names for remarkable peaks; the explorer asked all sorts of people, but with the exception of the case of Kanchinjinga, referred to above, he never got any name for a peak, though in a few cases they gave that of the nearest village. 
Several of the other peaks fixed by the explorer were very lotty ones, covered with perpetual snow to a great distance below their summits; those north of Mount Everest and Kanchinjinga are perhaps the most interesting, as being beyond the Himalayan watershed. One to the north of the road, between Shakia and Dingri, the explorer thought was very much loftier than any others.

'The explorer's route survey may be said in a rough way to give us a general idea as to how the mountain drainage runs between the Himalayan watershed, north-west of Kirong, and the point where Turner crossed it near Chumalári, up to the Bráhmáputra, or Sang-po River on the north from west of Janglache to Shigatze. The route between Kirong, Jong-kaJong, and Dingri Maidán is still a desideratum, as we are in the dark as to the size of the Palgu Cho Lake, which, however, it now appears will lie somewhat to the south of the approximate position which I gave it in my map showing the chief Pundit's route to Lhása.

A glance at the map at once shows what a large river the Arun must be, the area it drains being so very great. It is one of the few Himalayan rivers which has its source beyond the Himalayan range as seen from Hindustán, the others being the Indus, Sutlej, and Karnáli. The length of the eastern and western upper sources is very remarkable, extending on the one side to the north and east of Kanchinjinga, and on the other to the north and west of Mount Everest.

In the route survey made by explorer No. 9, from Dárjiling to Shigatze, and from Shigatze by Shakia, Dingri Maidán, Nilam, \&c., to Katmándu, the value of his pace has in the first instance been derived from the differences of latitude between the various places at which star observations for latitude were taken. A mean value of pace, viz. : $2 \cdot 45$ feet, derived from a mean of the values of each section, was adopted, and this mean value was applied to the number of paces, showing the differences of longitude for each section, and the value of the same in degrees and minutes was deduced therefrom in the usual way.

Taking the longitude of Dárjiling at $88^{\circ} 18^{\prime} 41^{\prime \prime}$, as determined by the triangulation of the Great Trigonometrical Survey, and applying the differences of longitude as determined above, the longitude of Shigatze, by Tatápáni, Chota Tápu, \&c., vide map, i.e., by the most direct route, would be $88^{\circ} 46^{\prime} 44^{\prime \prime}$.

Taking the longitude of Katmándu at $85^{\circ} 17^{\prime} 45^{\prime \prime}$, and applying the differences of longitude as above, between it and Shigatze, by Nilam, Dingri, Pil, \&c., the longitude of Shigatze would be $88^{\circ} 32^{\prime} 45^{\prime \prime}$.

On examining the map, howerer, it is at once apparent that VOL. XLV. 
the longitude of Shigatze, as determined by a route survey from Dárjiling, is likely to be more reliable than that derived from Katmándu, because the difference of longitude, between Dárjiling and Shigatze, is but $0^{\circ} 21^{\prime}$, while the difference between Katmándu and Shigatze, is $3^{\circ} 11^{\prime}$, or in other words the longitude of Shigatze would be very much more affected by an error in the value of the pace in the latter case than in the former. I have consequently decided upon using only the value as determined from Dárjiling.

In my report on the chief Pundit's exploration to Lhása, I explained that the longitude of Shigatze was determined by the route survey which $\mathrm{Mr}$. Turner made during his journey to Shigatze, combined with the route of the Pundit, Shigatze was computed to be in longitude $88^{\circ} 48^{\prime}$, a very close agreement with the value as determined above independently by explorer No. 9, viz., $88^{\circ} 47^{\prime}$. It may consequently be concluded that the longitudes of Shigatze and of Lhása, which depends on Shigatze, as given in my first map, are very close approximations, and it is gratifying to find that my reliance on Turner's route survey was not misplaced.

The explorer's work has stood all the usual tests satisfactorily, the average value of his pace, $2 \cdot 45$ feet as determined from the differences in latitude, is about what might be expected from a man of his stature. His latitude observations agree very well inter se, considering that he used but a small pocket sextant. His observations at Shigatze give much the same latitude as that derived from the chief Pundit's observations with a large sextant at that and other places.

His heights are the weakest part of his work, as, owing to the larger thermometers originally sent with him having been broken, he was reduced to take his boiling-point observations with a very small thermometer. The heights, however, are probably fair approximations, and give a good general idea of the great elevation of the upper part of his ground.

His bearings to peaks on either side of his road were more numerous than usual, and on the whole he was fairly successful in fixing the more conspicuous.

The exploration with its bearings, \&c., opens out the geography of nearly 30,000 square miles of what has hitherto been in many portions terra incognita and in others nearly so; the indications on our maps having been of course mostly conjectural. The exploration more especially elucidates the geography of the basin of the Arun or Arun-kosi River, the great eastern feeder, if not the main source of the great Kosi or Kosiki Kiver, which drains the whole of eastern Nepal. The courses of the upper feeders of the Arun have hitherto been a 
puzzle to geographers. The explorer's work also defines the course of the great western tributary of the Kosi River, viz., the Bhotia Kosi, of which we had previously no survey.

His route survey is 844 miles in length, of which 550 miles may be said to be over entirely new ground, and the remainder (though close to a line along which one European has travelled) had never been regularly surveyed before.

The explorer took latitude observations at 11 points upon which the work depends, and determined the height of 31 places. His work, I think, will prove a valuable addition to the Trans-Frontier geography of India.

List of Positions of the Chief Places as determined from the Route Survey of Explorer No. 9 in Nepal and Great Tibet.

\begin{tabular}{|c|c|c|c|c|c|}
\hline & Latituc & & Longitude. & Height. & Remarks. \\
\hline $\begin{array}{lllll}\text { Dúrjiling } & . . & . . & . . & . .\end{array}$ & 27 & & $88 \quad 19$ & $\begin{array}{l}\text { Feet. } \\
7,253\end{array}$ & From G.T.Survey. \\
\hline $\begin{array}{lllll}\text { Tatápáni } & . . & . . & . . & . .\end{array}$ & 283 & 36 & $88 \quad 8$ & 15,025 & \\
\hline 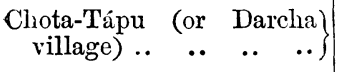 & 285 & 57 & $88 \quad 27$ & 14,558 & \\
\hline Shigatze (Tashilumbo) .. & 29 & 17 & $88 \quad 47$ & 11,822 & \\
\hline $\begin{array}{llllll}\operatorname{Pil} & . . & . . & . . & . . & . .\end{array}$ & $28:$ & 37 & $87 \quad 54$ & 13,259 & \\
\hline Dingri-Maidán town & 283 & 35 & $86 \quad 40$ & 13,865 & \\
\hline Nilam-Jong (or Kuti) & 28 & 9 & $86 \quad 5$ & 13,911 & \\
\hline Katmándu.. .. & 274 & 41 & $85 \quad 18$ & $\cdot \cdot$ & $\left\{\begin{array}{r}\text { From Crawford's } \\
\text { to G.T.S. Peaks. }\end{array}\right.$ \\
\hline Kabiri River, bank of $\quad .$. & &.$\cdot$ & $87 \quad 33$ & • & $\left\{\begin{array}{l}\text { No astronomical } \\
\text { latitude. }\end{array}\right.$ \\
\hline $\begin{array}{lll}\text { Narharia (Naria) } & . . & . .\end{array}$ & 26 & 26 & $86 \quad 45$ & .. & \\
\hline $\begin{array}{llll}\text { Dhankuta .. } & . . & . . & . .\end{array}$ & 26 & 56 & $87 \quad 21$ & 2,927 & \\
\hline $\begin{array}{llll}\text { Lámádong .. } & . . & . . & . .\end{array}$ & 271 & 10 & $86 \quad 52$ & .. & \\
\hline $\left.\begin{array}{ccccc}\text { Amtia on } & \text { bank of } & \text { Arun } \\
\text { River } & . . & . . & . . & . .\end{array}\right\}$ & 271 & 12 & $87 \quad 12$ & 1,798 & \\
\hline
\end{tabular}

The longitude of Shigatze is derived from Dárjiling by the route survey passing through Tatápáni and Chota-Tápu. In the map accompanying this memorandum, $88^{\circ} 40^{\prime}$ was assumed to be the longitude, using a mean between the values derived from Katmándu and Shigatze. In future compilations the positions as given on the map, will require to be corrected to those given above. 
340 Montgomerie on Trans-Himalayan Explorations, 1871.

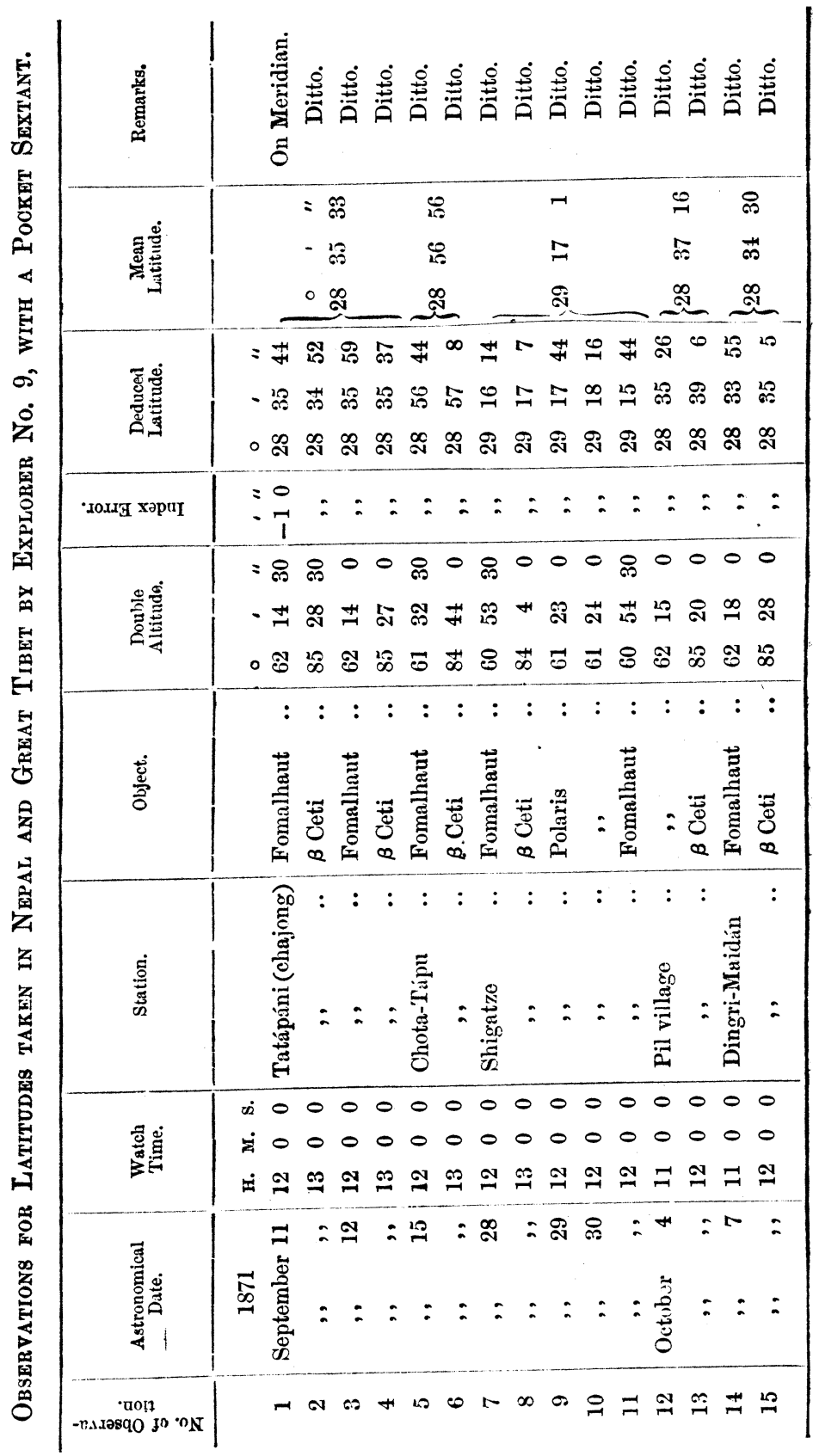


Montgcmerie on Trans-Himalayan Explorations, 1871. 341

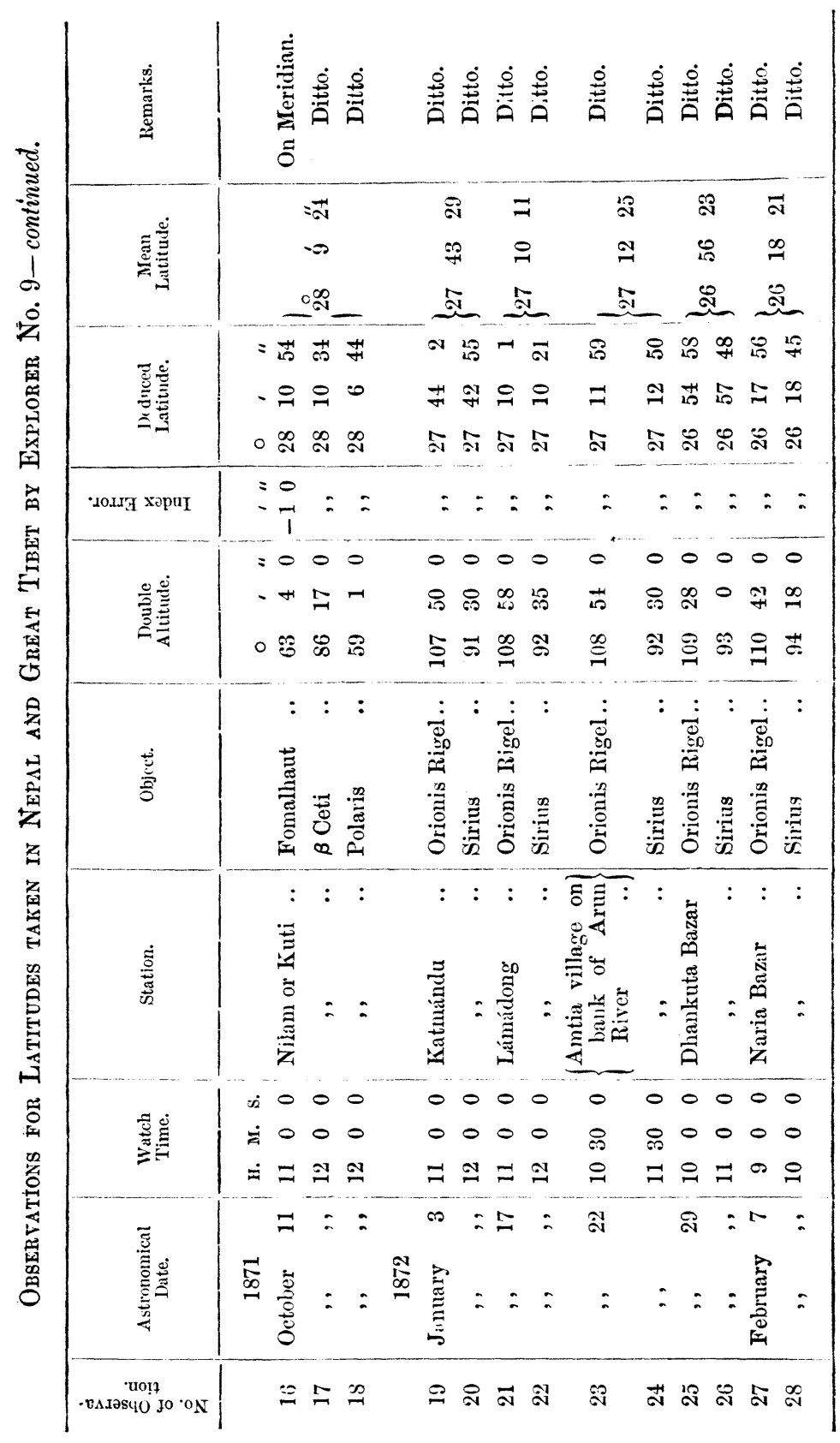


342 Montgomerie on Trans-Himalayan Explorations, 1871.

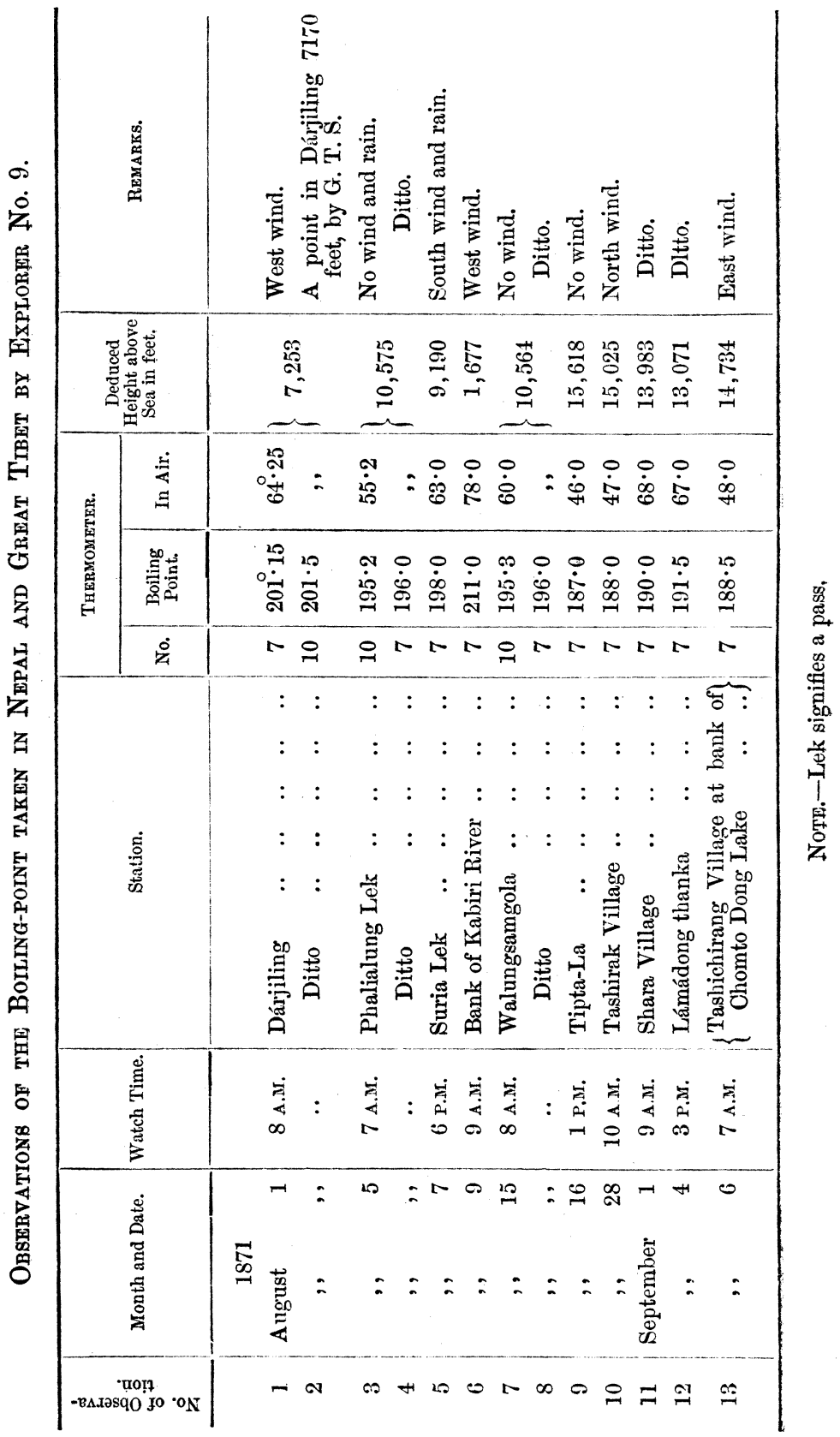


Montgomerie on Trans-Himalayan Explorations, 1871. 343

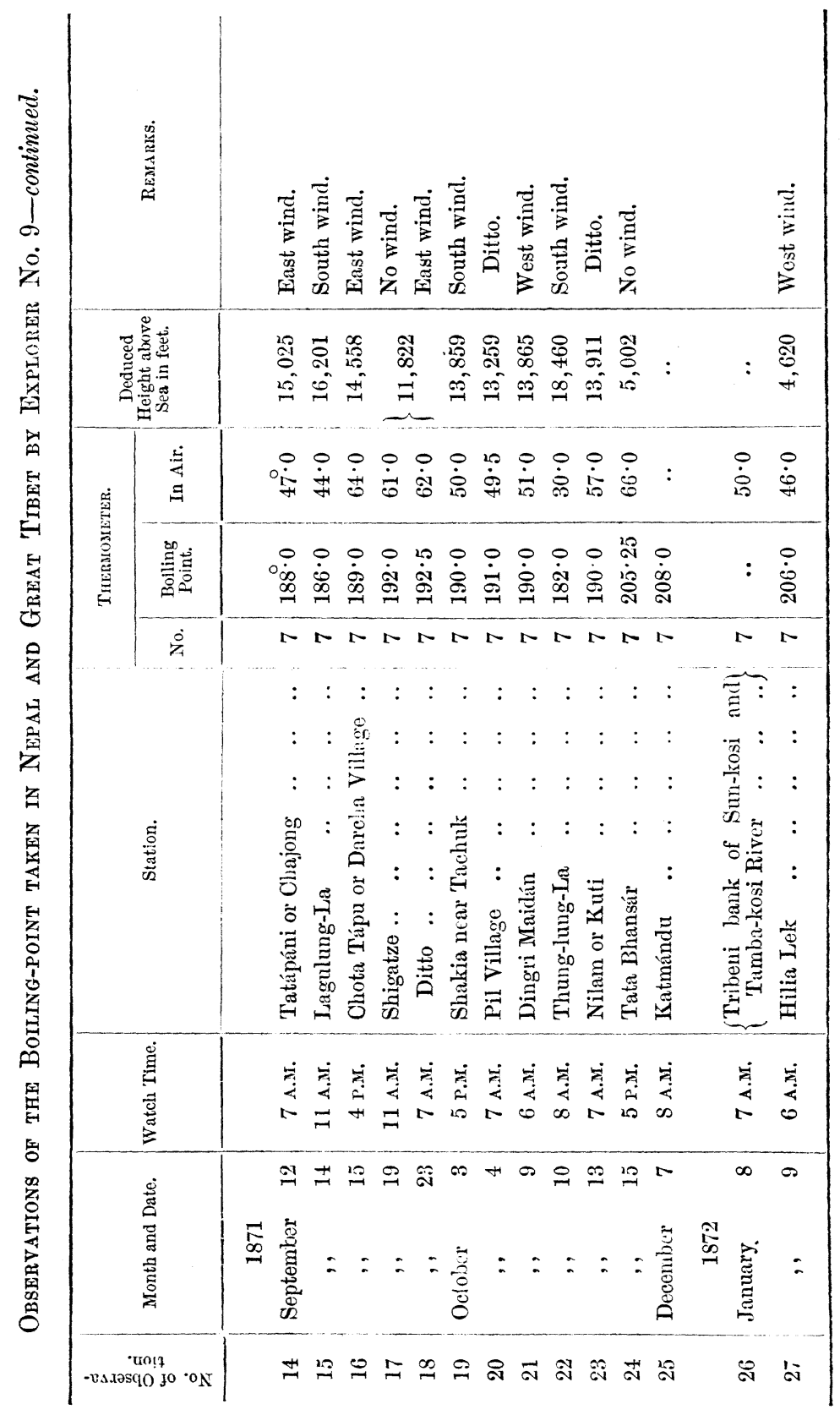


344 Montgomerie on Trans-Himalayan Explorations, 1871.

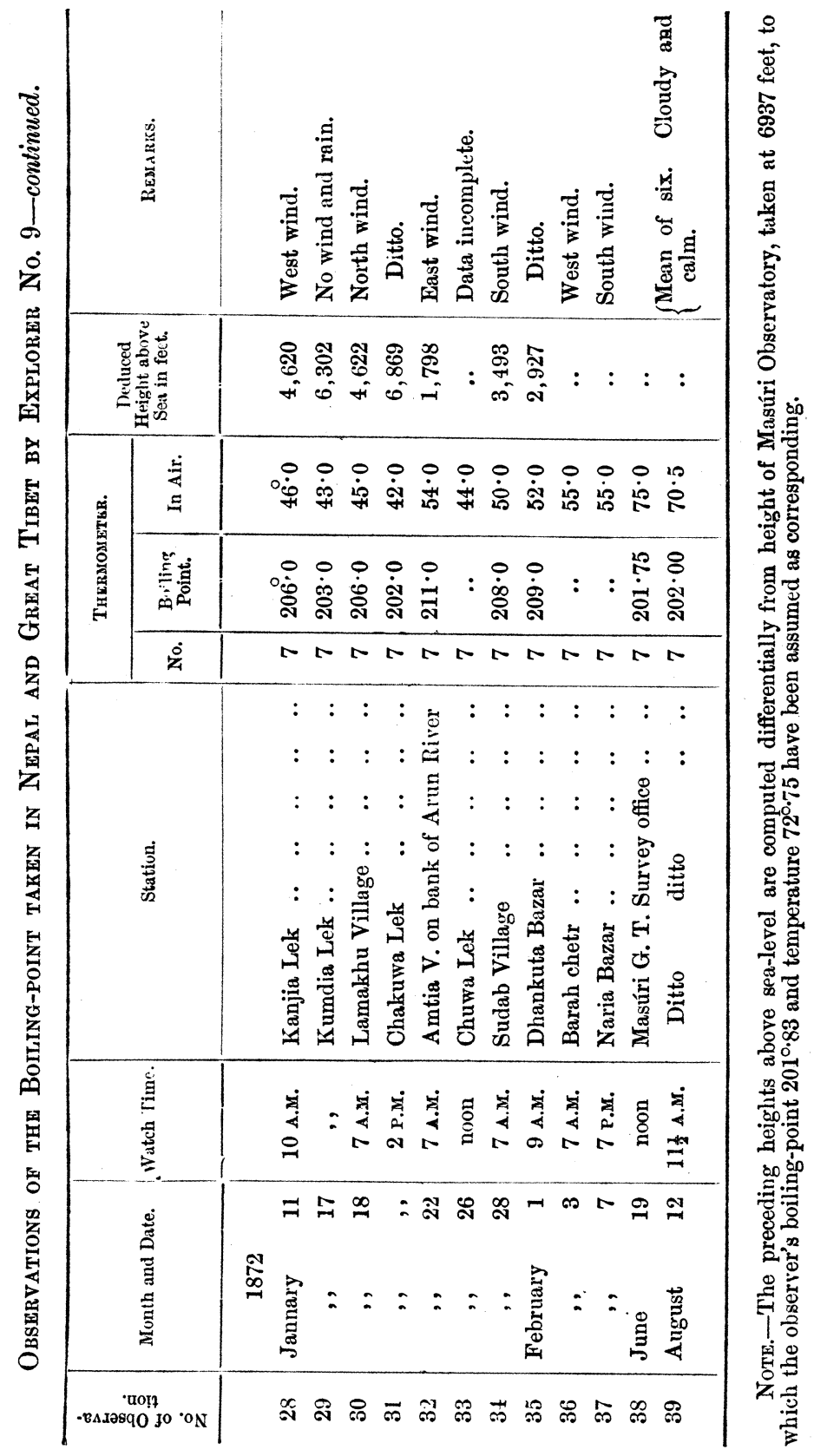


Montgomerie on Trans-Himalayan Explorations, 1871. 345

Route Strvey from DárJiling (Thánah) to Shigatze (Market Place).

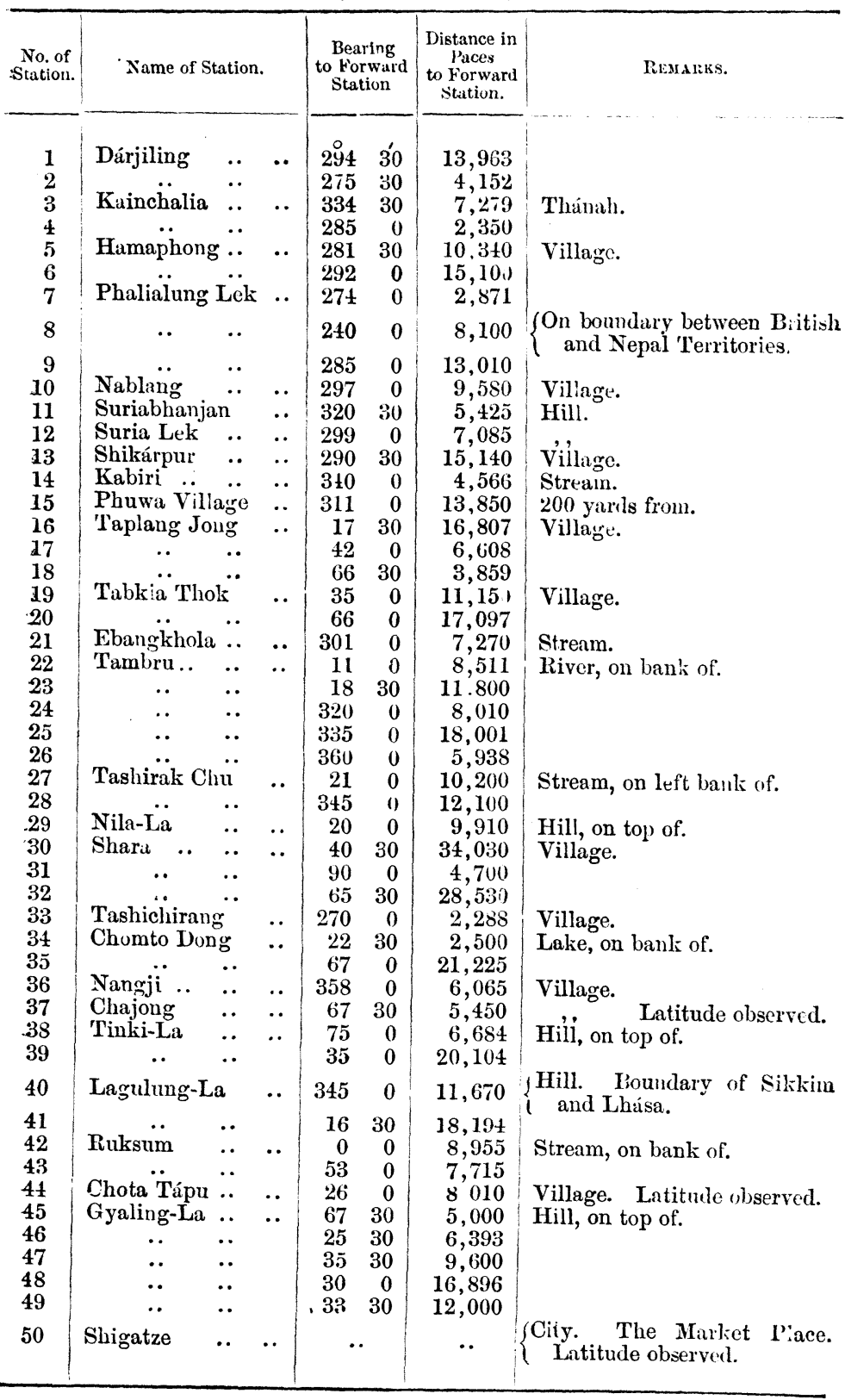




\section{Montgomerie on Trans-Himalayan Explorations, 1871.}

From Changma (Village near Shigatze) to Katmándu.

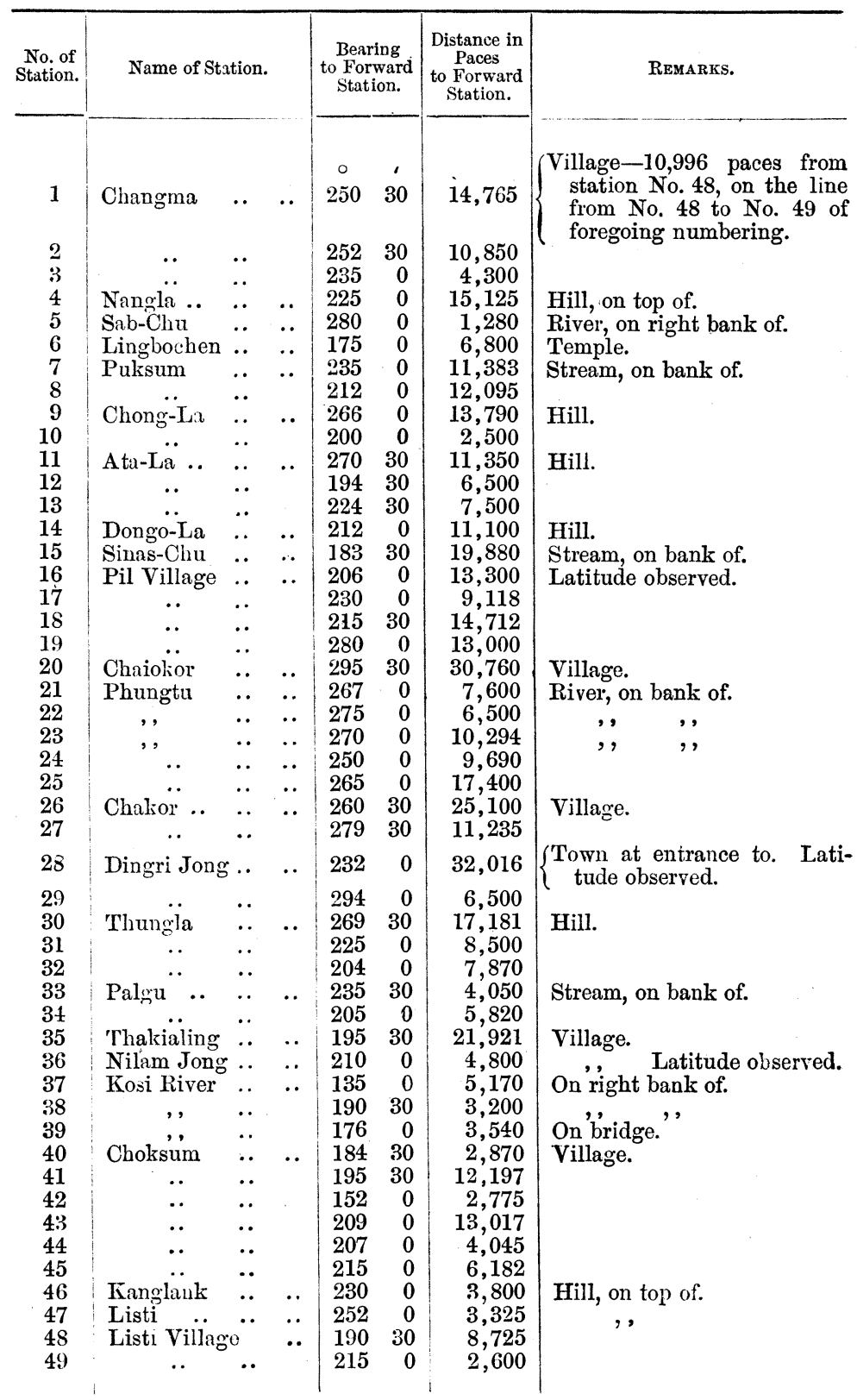


Montgonerie on Trans-Himalayan Explorations, 1871. 347

From Changma (Village near Shigatze) to Katmándu-continued.

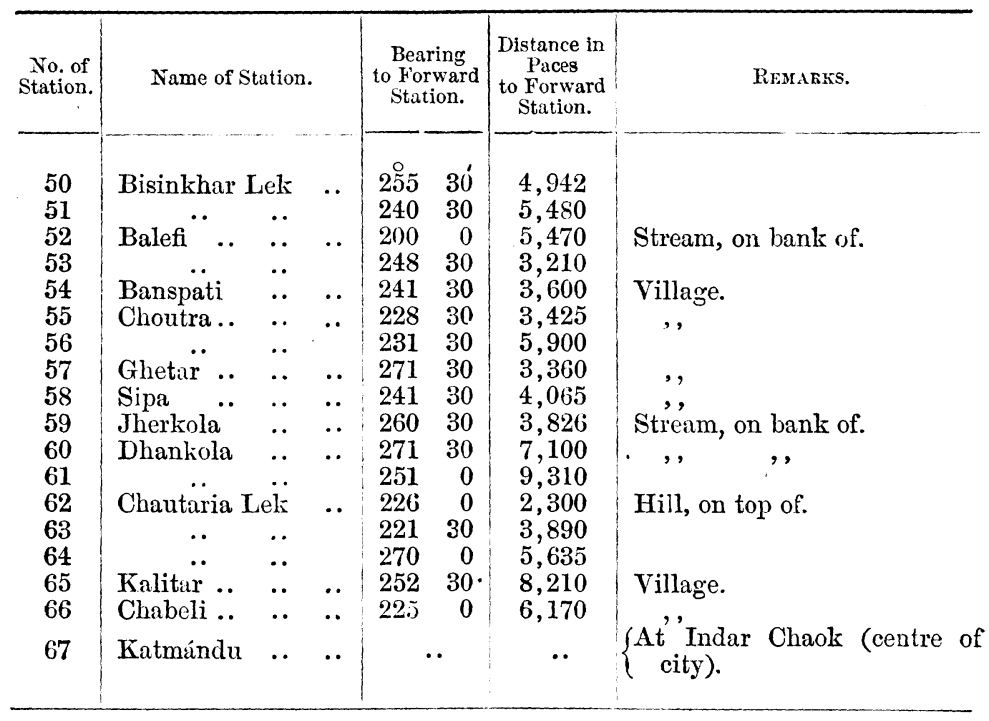

From Katmándo (Asan Tol) to Taplang Jong (Station No. 16 of Route from Dárjiling to Shigatze).

\begin{tabular}{|c|c|c|c|c|c|c|}
\hline 1 & Katmándu .. & .. & 112 & 0 & 7,575 & $\left\{\begin{array}{c}\text { Asan Tol. Latitude observed } \\
\text { on this line, 1025 paces }\end{array}\right.$ \\
\hline 2 & Dimi Village & .. & 110 & 0 & 2,250 & \\
\hline 3 & .... & & 106 & 0 & 3,710 & \\
\hline 4 & & & 115 & 0 & 6,300 & \\
\hline 5 & Bist Village... & .. & 103 & 0 & 2,335 & \\
\hline 6 & Burapa , , .. & .. & 129 & 0 & 4,060 & \\
\hline 7 & .. & & 113 & 30 & 5,660 & \\
\hline 8 & Nabna Lek .. & .. & 126 & 30 & 4,700 & \\
\hline 9 & Dabchia Village & .. & 122 & 0 & 3,230 & \\
\hline 10 & .. $\quad .$. & & 118 & 30 & 4,850 & \\
\hline 11 & .. & & 66 & 30 & 2,500 & \\
\hline 12 & .. & & 123 & 30 & 4,415 & \\
\hline 13 & .. & & 135 & 30 & 6,825 & \\
\hline 14 & .. & & 112 & 0 & 5,200 & \\
\hline 15 &.. & & 110 & 0 & 4,910 & \\
\hline 16 & $\ddot{.}$ & & 127 & 0 & 7,800 & \\
\hline 17 & Jhangajholi .. & .. & 105 & 0 & 4,786 & Village. \\
\hline 18 & Mulkotir $\quad .$. & .. & 127 & 30 & 6,400 & ,, \\
\hline 19 & .. & & 74 & 0 & 2,415 & \\
\hline 20 & $\ddot{.}$ & & 144 & 0 & 5,500 & \\
\hline 21 & Tribeni .. & .. & 92 & 0 & 7,200 & Junction of two streams. \\
\hline 22 & Bedana .. & .. & 110 & 0 & 3.950 & Village. \\
\hline 23 & .. & & 100 & 0 & 5,700 & \\
\hline 24 & Hilia Village & .. & 32 & 0 & 3,000 & \\
\hline 25 & .. & & 35 & 0 & 3,500 & \\
\hline 26 & .. & & 112 & 0 & 2,000 & \\
\hline
\end{tabular}


348 Montgomerie on Trans-Himalayan Explorations, 1871.

From Katmándu (Asan Tol) to Taplang Jong-continued.

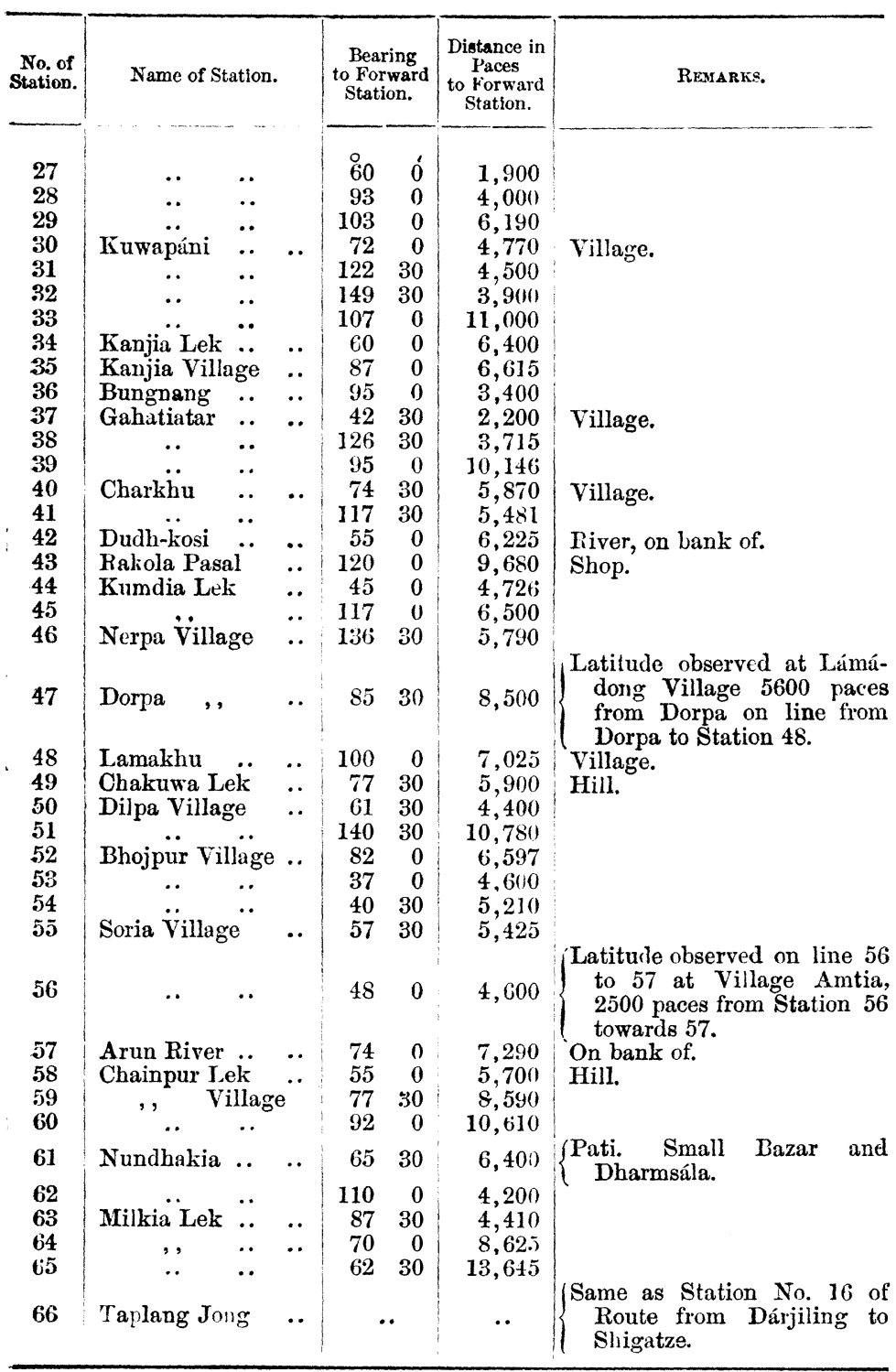


MIONTGOMERIE on Trans-Himalayan Explorations, 1871. 349

From Kabiri Dharmsala (Station No. 14 of Route from Dárjiling to Shigatze) to Naria Bazar (Kotwáli).

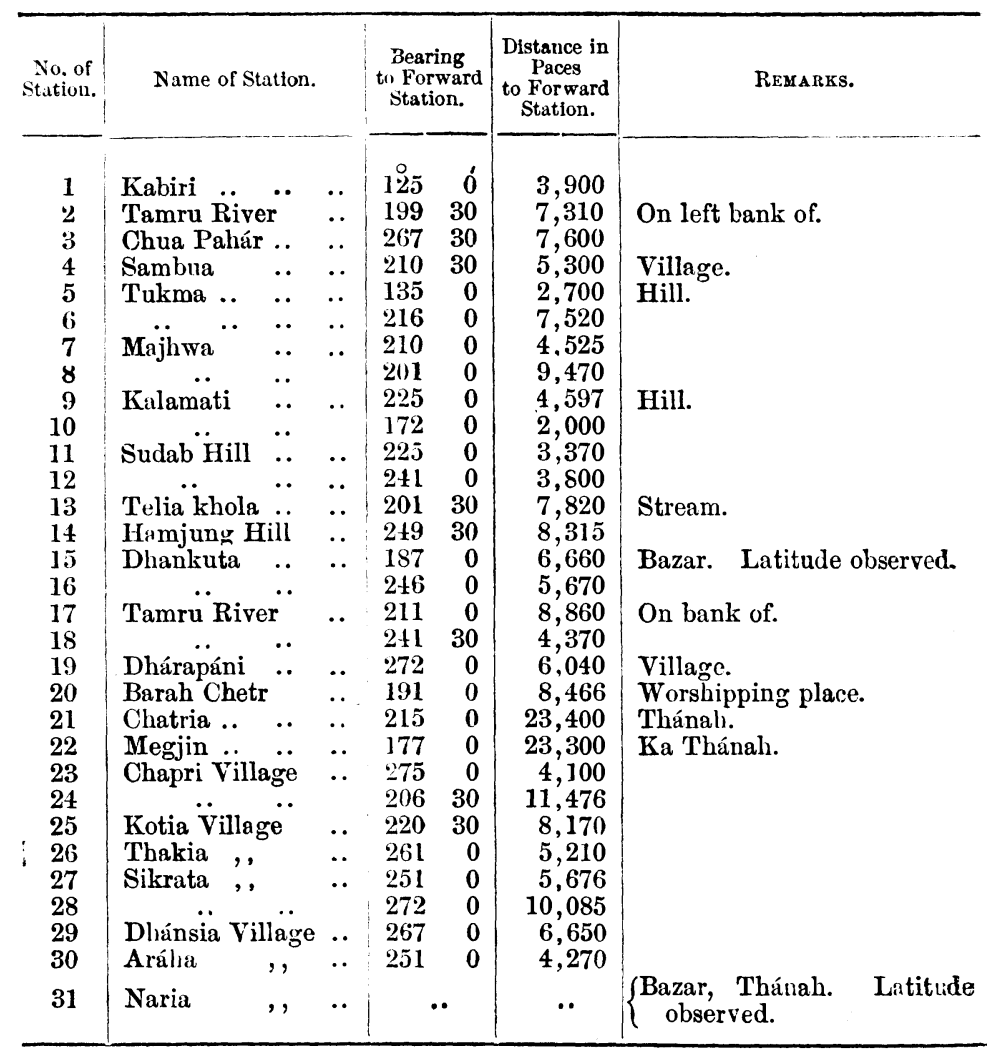




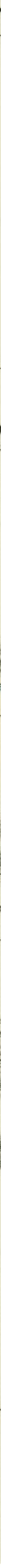




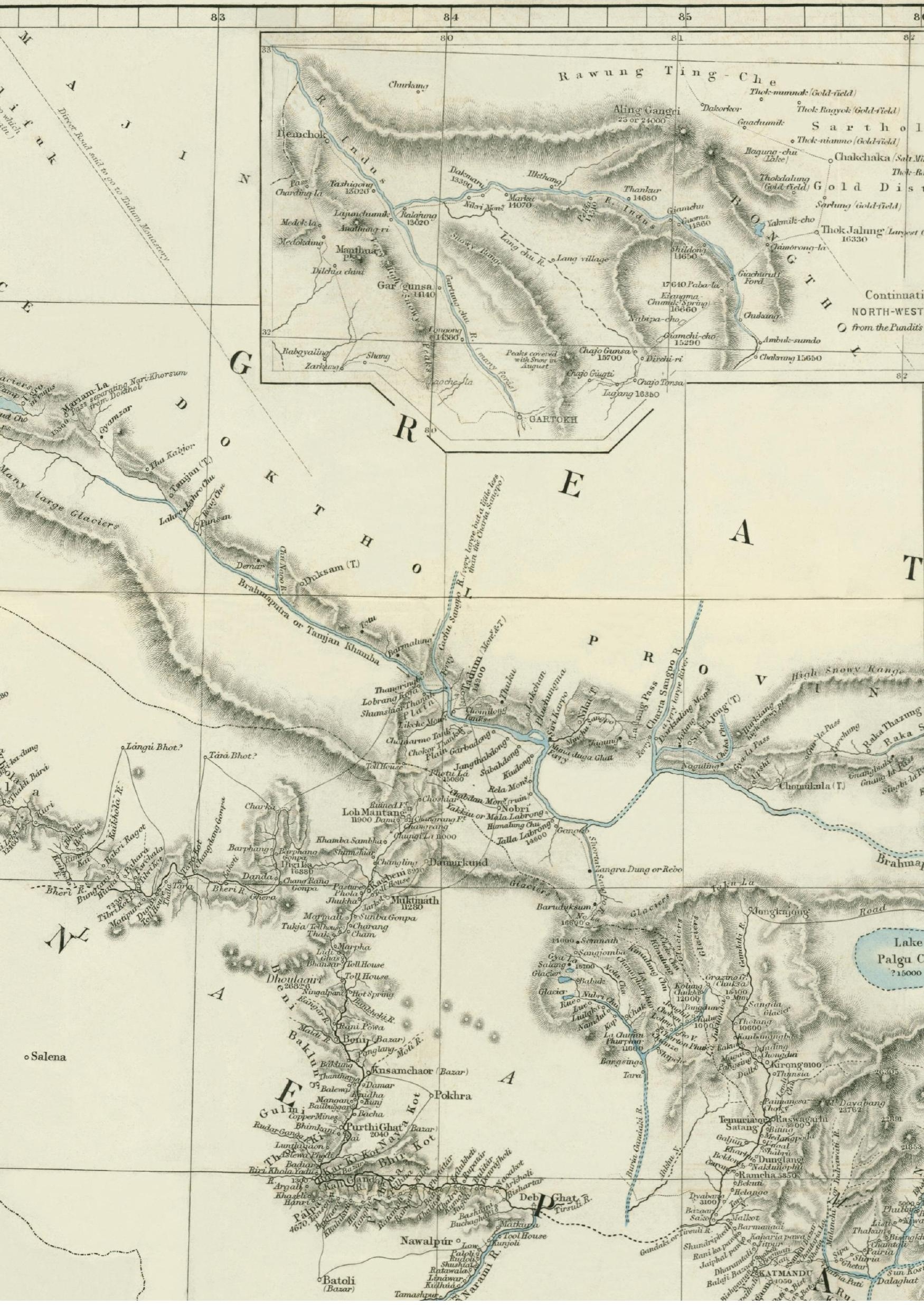

This content downloaded from 92.63.101.146 on Sat, 28 Jun 2014 13:10:16 PM All use subject to JSTOR Terms and Conditions 
Map showing

ROUTES OF NATIVE EXPLORERS in

\section{TIBT $\mathbb{E} \mathbb{A} \mathbb{N} \mathbb{N}$ PA 1}

to Illustrate the Papers

by

MP Markham, \& Lient. Colonel T. G. Montgomerie.

English Miles

in 20 30 to bo 100

Geographical Miles

(T.) Tarjam (Post House)

- Camp

1020
(T.) Tarjam (Post House,

$A$

0

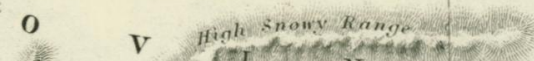

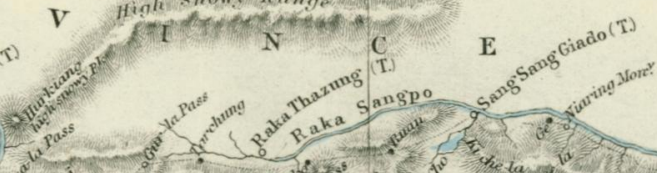

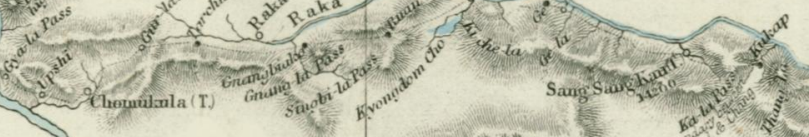

T

I

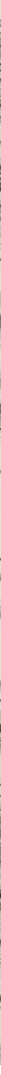




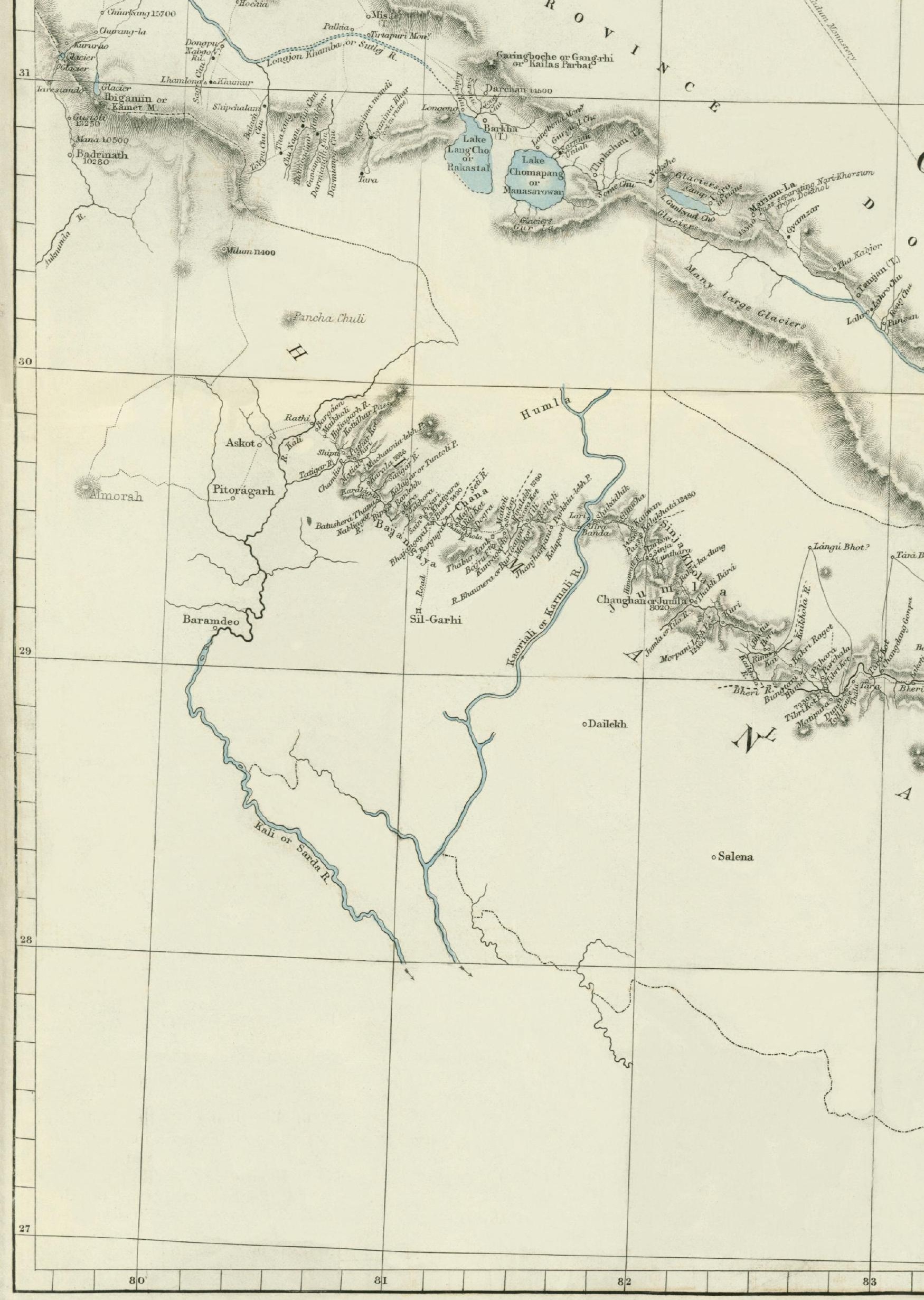



